\title{
Influence of powder from tuber topinambur on the consumer properties of venison cutlets in storage
}

\author{
Inessa Zachesova ${ }^{1}$, Stanislav Kolobov ${ }^{2,3,}$, and Natalia Shagaeva ${ }^{1}$ \\ ${ }^{1}$ Moscow State Academy of Veterinary Medicine and Biotechnology - MVA named after K.I. \\ Skryabin \\ ${ }^{2}$ Plekhanov Russian University of Economics \\ ${ }^{3}$ Russian Presidential Academy of National Economy and Public Administration
}

\begin{abstract}
For the first time, studies were conducted on changes in the consumer properties of cutlets with powder from Jerusalem artichoke tubers during storage. In solving these problems, generally accepted special organoleptic, physicochemical, microbiological, structural and mechanical methods for studying the properties of finished products were used. It has been established that venison cutlets with Jerusalem artichoke tubers powder are characterized by greater stability of consumer properties compared to cutlets without Jerusalem artichoke tubers powder. During freezing and subsequent storage of cutlets, a decrease in water binding capacity and an increase in losses during heat treatment were noted. It should be noted that these changes were less pronounced in cutlets with powder from Jerusalem artichoke tubers, compared with cutlets without powder from Jerusalem artichoke tubers. It was found that cutlets with powder from Jerusalem artichoke tubers produced with powder from Jerusalem artichoke tubers showed a lower level of lipid oxidation compared to cutlets without powder from Jerusalem artichoke tubers. The results of the tasting assessment confirmed the high quality of venison cutlets with Jerusalem artichoke tubers powder.
\end{abstract}

\section{Introduction}

Venison has dietary properties - high in protein, low in fat, fairly high in zinc, copper, and iron as compared to other meat raw materials, such as horse meat, beef, and pork $[1,2,3]$.

High nutritional and biological value of venison, good meat quality of deer can significantly expand the resources of raw meat for the production of meat and meatcontaining products and increase the range of products, including diet.

At present, representatives of the peoples of the North, Siberia, and the Far East are engaged in reindeer husbandry in Russia. Reindeer husbandry is a promising industry that allows the use of feed resources of the taiga and tundra, as well as the labor resources of the indigenous peoples of the North for the production and delivery to the market of valuable

\footnotetext{
*Corresponding author: 97rus@mail.ru
} 
types of various products: gourmet meat, raw materials for the manufacture of medicines, leather and fur raw materials, etc. $[2,3]$.

At the present stage of the development of nutrition science, there is a need to increase the nutritional value of food products. One of the priority areas is the creation of food products with a high content of biologically valuable compounds: vitamins, minerals, dietary fiber and others. The basis for the production of such products is the integrated use of animal and vegetable raw materials, which increase the resistance of the human body to adverse environmental factors.

In recent years, there has been a trend in the production of food products enriched with plant-based nutritional supplements containing physiologically functional ingredients. To this end, for the production of meat products using food additives from processed products of pumpkin, Jerusalem artichoke, mustard, corn, fruit and vegetable powders, which serve as a source of proteins, vitamins, minerals, carbohydrates, dietary fiber $[4,5,6]$.

Jerusalem artichoke is a promising raw material for the production of food additives for use in the meat industry. Jerusalem artichoke tubers have a high biological value. The powder of Jerusalem artichoke tubers contains $5 \%$ glucose and $95 \%$ fructose from the total content of monosaccharides. High fructose and low glucose are important for patients with diabetes, since fructose is involved in the same metabolic processes as glucose, while replacing it with a lack of insulin [7-12].

The powder of Jerusalem artichoke tubers contains a fairly high amount of dietary fiber, pectin substances. Dietary fibers in combination with proteins provide high water-absorbing and water-holding abilities of food additives. These properties are of great importance for the regulation and formation of technological properties of complex structured food systems, which include minced systems [6-12].

The rhythm and lifestyle makes consumers save time, including cooking. In this regard, the number of consumers of semi-finished meat products, including meatballs, is growing [13]. We have developed a recipe for venison cutlets with the addition of $8 \%$ powder from Jerusalem artichoke tubers. As a result of research, it was found that cutlets developed according to the developed recipe have high consumer properties.

Further research was aimed at establishing the effect of Jerusalem artichoke tubers powder on the stability of consumer properties of venison cutlets during storage.

In accordance with the goal, experimental studies were aimed at solving the following problems:

- to study the dynamics of organoleptic quality indicators of cutlets during storage;

- to study the dynamics of physico-chemical quality indicators of cutlets during storage;

- to study the dynamics of the structural and mechanical characteristics of cutlets during storage;

- $\quad$ to study the dynamics of acid, peroxide and thiobarbituric lipid numbers of cutlets during storage;

- to study the dynamics of the total microbial contamination of cutlets during storage.

\section{Materials and methods}

According to the recipe we developed, frozen venison cutlets were developed with the addition of $8 \%$ powder from Jerusalem artichoke tubers instead of raw meat, which served as objects for further research. We also developed venison cutlets without adding powder from Jerusalem artichoke tubers, which served as a control sample. 
In solving these problems, generally accepted special organoleptic, physicochemical, microbiological, structural and mechanical methods for studying the properties of finished products were used.

Quality indicators of venison cutlets with Jerusalem artichoke tubers powder were determined at $0,36,72,108$ days of storage. Cutlets, packed in plastic trays, hermetically sealed, were stored in the freezer at a temperature of minus $8^{\circ} \mathrm{C}$.

Organoleptic characteristics of cutlets were determined in accordance with GOST 99592015 «Meat and meat products. General conditions for organoleptic assessment». Evaluated indicators: appearance, color in section, smell, taste, texture, juiciness. Appearance, sectional view, color and smell of cutlets were evaluated raw. The taste was evaluated after heat treatment - frying. The assessment was carried out by a tasting commission, consisting of seven tasters, on a nine-point scale. Each indicator was evaluated and a general average rating was set.

The penetration depth was determined according to GOST R 50814-95 «Meat products. Methods for determining penetration by a cone and a needle indenter» on an automatic penetrometer of the company «Labor». The principle of operation of the penetrometer is to automatically measure the degree of penetration, expressed in $0,1 \mathrm{~mm}$ of the distance at which the indenter (cone) penetrates the test material perpendicular to its surface at a temperature of $20^{\circ} \mathrm{C}$ for $5 \mathrm{~s}$.

The ultimate shear stress and cutting work were determined on an Instron universal testing machine in accordance with the manufacturer's recommendations.

The number of bacteria of the group of Escherichia coli (coliform bacteria) in the semifinished products was determined according to GOST 31747-2012 «Food. Methods for detecting and determining the number of bacteria of the group of Escherichia coli (coliform bacteria)».

The amount of mesophilic aerobic and facultative anaerobic microorganisms in semifinished products was determined according to GOST 10444.15-94 «Food products. Methods for determining the number of mesophilic aerobic and facultative anaerobic microorganisms». The method for determining the amount of mesophilic aerobic and facultative anaerobic microorganisms inoculated into agarized culture media is based on seeding the product or diluting a portion of the product into the culture medium, incubating the crops, counting all grown visible colonies.

Mold fungi in semi-finished products were determined according to GOST 10444.122013 «Microbiology of food products and animal feed. Methods for detecting and counting the number of yeast and molds».

The acid number in the semi-finished products was determined according to GOST R 55480-2013 «Meat and meat products. Method for determining the acid number». The method is based on titration of free fatty acids with a solution of potassium hydroxide or sodium hydroxide.

The peroxide value in semi-finished products was determined according to GOST 34118-2017 «Meat and meat products. Method for determining the peroxide value». The method is based on the reaction of the interaction of primary products of fat oxidation (peroxides and hydroperoxides) with potassium iodide in an acidic medium, followed by titration with sodium thiosulfate solution and quantitative determination of the released iodine.

Thiobarbituric number in semi-finished products was determined according to GOST R 55810-2013 «Meat and meat products. The method for determining the thiobarbituric number». The method is based on the reaction of thiobarbituric acid with malonic aldehyde formed during the oxidation of unsaturated fatty acids contained in meat, and on the subsequent measurement of the absorption of the resulting color on a spectrophotometer.

Processing of the data was carried out using methods of mathematical statistics. 


\section{Results}

According to the recommended methodological guidelines 4.2.1847-04 «Sanitary and epidemiological assessment of the justification of shelf life and storage conditions of food products» of the recommended research scheme for semi-finished products depending on the expected storage periods, the quality control of the samples of cutlets was carried out on $0,36,72$ and 108 days of storage.

The results of the assessment of organoleptic quality indicators of cutlets during storage are presented in table 1.

Table 1. Dynamics of organoleptic quality indicators of cutlets during storage.

\begin{tabular}{|c|c|c|c|c|c|c|c|c|}
\hline \multirow[b]{3}{*}{$\begin{array}{l}\text { Name of } \\
\text { indicator }\end{array}$} & \multicolumn{8}{|c|}{ Rating, points } \\
\hline & \multicolumn{2}{|c|}{0 days of storage } & \multicolumn{2}{|c|}{36 days of storage } & \multicolumn{2}{|c|}{72 days of storage } & \multicolumn{2}{|c|}{108 days of storage } \\
\hline & $\begin{array}{c}\text { Jerusale } \\
\text { m } \\
\text { artichoke } \\
\text { tubers } \\
\text { without } \\
\text { powder }\end{array}$ & $\begin{array}{l}\text { Cutlets } \\
\text { with } \\
\text { powder } \\
\text { from } \\
\text { Jerusal } \\
\text { em } \\
\text { articho } \\
\text { ke } \\
\text { tubers }\end{array}$ & $\begin{array}{c}\text { Jerusal } \\
\text { em } \\
\text { articho } \\
\text { ke } \\
\text { tubers } \\
\text { without } \\
\text { powder }\end{array}$ & $\begin{array}{c}\text { Cutlets } \\
\text { with } \\
\text { powder } \\
\text { from } \\
\text { Jerusale } \\
\text { m } \\
\text { artichoke } \\
\text { tubers }\end{array}$ & $\begin{array}{c}\text { Jerusal } \\
\text { em } \\
\text { articho } \\
\text { ke } \\
\text { tubers } \\
\text { without } \\
\text { powder }\end{array}$ & $\begin{array}{c}\text { Cutlets } \\
\text { with } \\
\text { powder } \\
\text { from } \\
\text { Jerusale } \\
\text { m } \\
\text { artichoke } \\
\text { tubers }\end{array}$ & $\begin{array}{c}\text { Jerusal } \\
\text { em } \\
\text { articho } \\
\text { ke } \\
\text { tubers } \\
\text { without } \\
\text { powder }\end{array}$ & $\begin{array}{c}\text { Cutlets } \\
\text { with } \\
\text { powder } \\
\text { from } \\
\text { Jerusale } \\
\text { m } \\
\text { artichoke } \\
\text { tubers }\end{array}$ \\
\hline Appearance & $\begin{array}{l}n \\
0 \\
0 \\
\infty \\
\infty\end{array}$ & 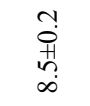 & $\begin{array}{l}\text { ñ } \\
\stackrel{+}{n} \\
\infty \\
\infty\end{array}$ & $\begin{array}{l}\dddot{0} \\
\stackrel{+}{n} \\
\infty\end{array}$ & 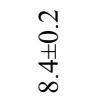 & $\begin{array}{l}+ \\
\stackrel{+}{+} \\
\dot{+} \\
\infty\end{array}$ & $\begin{array}{l}\text { N̦ } \\
\text { サn } \\
\text { ஸ் }\end{array}$ & 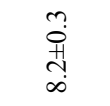 \\
\hline $\begin{array}{l}\text { Cutaway } \\
\text { Color }\end{array}$ & $\begin{array}{l}\text { Na } \\
\stackrel{H}{+} \\
\stackrel{\infty}{0}\end{array}$ & $\begin{array}{l}\ddot{0} \\
\stackrel{1}{1} \\
\infty\end{array}$ & 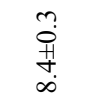 & $\begin{array}{l}\ddot{0} \\
+ \\
\infty \\
\infty\end{array}$ & $\begin{array}{l}\stackrel{+}{0} \\
\stackrel{0}{+} \\
\text { ஸे }\end{array}$ & $\begin{array}{l}\ddot{+} \\
+1 \\
\text { ஸ் }\end{array}$ & $\begin{array}{c}\text { ํ. } \\
\text { サn } \\
\infty\end{array}$ & $\begin{array}{l}\dddot{m} \\
\stackrel{+}{+} \\
\infty\end{array}$ \\
\hline Smell & $\begin{array}{l}\breve{.} \\
\stackrel{+}{+} \\
\infty \\
\infty\end{array}$ & $\begin{array}{l}\text { r } \\
\stackrel{+}{H} \\
\infty \\
\infty\end{array}$ & $\begin{array}{l}n \\
0 \\
+1 \\
\infty\end{array}$ & $\begin{array}{l}\text { ra } \\
\stackrel{+}{H} \\
\infty \\
\infty\end{array}$ & $\begin{array}{l}\text { N̦ } \\
\stackrel{+}{H} \\
\infty \\
\infty\end{array}$ & $\begin{array}{l}+ \\
\stackrel{0}{+} \\
\infty \\
\infty\end{array}$ & 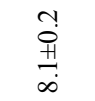 & $\begin{array}{l}\dddot{1} \\
\stackrel{1}{+} \\
\sim \\
\infty\end{array}$ \\
\hline Taste & $\begin{array}{l}n \\
\stackrel{n}{+} \\
\stackrel{\infty}{+}\end{array}$ & $\begin{array}{l}\overrightarrow{0} \\
\stackrel{+}{+} \\
\dot{\infty}\end{array}$ & $\begin{array}{l}n \\
\stackrel{n}{+} \\
+\end{array}$ & $\begin{array}{l}\overrightarrow{0} \\
\stackrel{+}{+} \\
\dot{\infty}\end{array}$ & $\begin{array}{l}n \\
\stackrel{n}{1} \\
\infty \\
\infty\end{array}$ & $\begin{array}{l}+ \\
0 \\
m \\
\infty\end{array}$ & $\frac{\substack{0 \\
\oplus \\
\infty}}{\infty}$ & $\begin{array}{l}\overrightarrow{0} \\
\overrightarrow{+} \\
\dot{\infty}\end{array}$ \\
\hline Consistency & 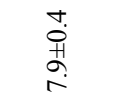 & $\begin{array}{l}\text { r } \\
\stackrel{+}{H} \\
n \\
\infty\end{array}$ & $\begin{array}{l}-1 \\
+ \\
\infty \\
\infty\end{array}$ & $\begin{array}{c}\text { N̦ } \\
\stackrel{+}{+} \\
\dot{\infty}\end{array}$ & 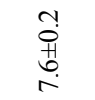 & $\begin{array}{l}m \\
? \\
+ \\
\infty \\
\infty\end{array}$ & ִֻ & $\begin{array}{l}\stackrel{+}{\circ} \\
\stackrel{+}{+} \\
\dot{\infty}\end{array}$ \\
\hline Succulence & $\begin{array}{c}n \\
0 \\
+1 \\
\infty \\
\end{array}$ & $\begin{array}{l}\overrightarrow{0} \\
\text { Hु } \\
\infty \\
\infty\end{array}$ & $\begin{array}{l}\stackrel{2}{o} \\
\text { +1 } \\
\end{array}$ & $\begin{array}{l}n \\
0 \\
+1 \\
\infty\end{array}$ & $\begin{array}{l}\stackrel{+}{0} \\
+ \\
\\
r\end{array}$ & $\begin{array}{l}m \\
\stackrel{1}{1} \\
m \\
\infty\end{array}$ & $\begin{array}{l}\text { Nִ } \\
\text { サn } \\
\text { ñ }\end{array}$ & $\frac{\dddot{m}}{\overbrace{0}^{+}}$ \\
\hline $\begin{array}{l}\text { Overall } \\
\text { quality } \\
\text { rating }\end{array}$ & $\begin{array}{l}n \\
\dddot{n} \\
\dddot{1} \\
\infty\end{array}$ & 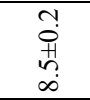 & $\begin{array}{l}m \\
0 \\
+1 \\
\text { ஸे }\end{array}$ & $\begin{array}{l}\text { N̦ } \\
\stackrel{+}{+} \\
\dot{+} \\
\infty\end{array}$ & $\begin{array}{l}+ \\
0 \\
0 \\
\infty\end{array}$ & 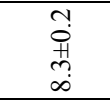 & 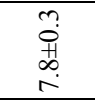 & $\begin{array}{l}\overrightarrow{0} \\
\overrightarrow{+} \\
\dot{\infty}\end{array}$ \\
\hline
\end{tabular}

When assessing the organoleptic quality indicators of cutlets, it was found that cutlets with powder from Jerusalem artichoke tubers were characterized by higher ratings not only on day 0 , but also during the entire storage period, compared with cutlets without powder from Jerusalem artichoke tubers (Table 1). It was found that the storage of cutlets for 108 days does not cause significant changes in the organoleptic characteristics of cutlets. By the end of the storage period, the surface of the patties with powder from Jerusalem artichoke tubers and the control sample darkened slightly, which is explained by the processes of interaction of hemoglobin and myoglobin with atmospheric oxygen, and the formation of metmyoglobin. The change in the consistency and juiciness of cutlets is associated with a 
certain decrease in the free moisture content during storage. It should be noted that throughout the entire storage period, cutlets with powder from Jerusalem artichoke tubers were characterized by higher values of organoleptic indicators.

The results of the study of the dynamics of physico-chemical parameters of cutlets are presented in table 2 .

Table 2. The Dynamics of physico-chemical characteristics of cutlets during storage.

\begin{tabular}{|l|c|c|c|c|}
\hline \multirow{2}{*}{ Sample Name } & $\begin{array}{c}\text { Shelf life, } \\
\text { day }\end{array}$ & $\begin{array}{c}\text { The total } \\
\text { moisture } \\
\text { content, } \%\end{array}$ & $\begin{array}{c}\text { Water binding } \\
\text { capacity,\% to } \\
\text { total moisture }\end{array}$ & $\begin{array}{c}\text { Mass loss } \\
\text { during heat } \\
\text { treatment, } \%\end{array}$ \\
\hline \multirow{2}{*}{$\begin{array}{l}\text { Jerusalem } \\
\text { artichoke tubers } \\
\text { without powder }\end{array}$} & 0 & $62.12 \pm 0.64$ & $65.45 \pm 0.62$ & $23.25 \pm 0.65$ \\
\cline { 2 - 5 } & 36 & $61.66 \pm 0.85$ & $63.34 \pm 0.77$ & $24.36 \pm 0.45$ \\
\cline { 2 - 5 } & 72 & $59.79 \pm 0.71$ & $62.43 \pm 0.92$ & $25.78 \pm 0.73$ \\
\hline $\begin{array}{l}\text { Cutlets with } \\
\text { powder from }\end{array}$ & 0 & $58.55 \pm 0.67$ & $61.21 \pm 0.79$ & $26.84 \pm 0.55$ \\
\cline { 2 - 5 } $\begin{array}{l}\text { Jerusalem } \\
\text { artichoke tubers }\end{array}$ & 36 & $64.93 \pm 0.52$ & $72.38 \pm 0.53$ & $20.26 \pm 0.58$ \\
\cline { 2 - 5 } & 72 & $62.95 \pm 0.77$ & $71.61 \pm 0.68$ & $21.10 \pm 0.59$ \\
\cline { 2 - 5 } & 108 & $61.84 \pm 0.89$ & $70.75 \pm 0.75$ & $21.79 \pm 0.55$ \\
\hline \multirow{2}{*}{ Canyyyyy}
\end{tabular}

As can be seen from the data of table 2, in the samples of cutlets with powder from Jerusalem artichoke tubers, in comparison with the control sample of cutlets without powder from Jerusalem artichoke tubers, the total moisture content and water-binding ability are slightly higher. This trend has been observed throughout the storage period. During storage, in samples of cutlets with powder from Jerusalem artichoke tubers and cutlets without powder from Jerusalem artichoke tubers, the total moisture content decreased due to sublimation. It was found that in samples of cutlets with Jerusalem artichoke tubers powder after freezing and throughout the storage period, the content of firmly bound moisture was higher than in control samples of cutlets, which is explained by the addition of Jerusalem artichoke tubers to the cutlet recipe. During storage of cutlets in a frozen state, changes in proteins occurred, causing a decrease in their water-binding ability. This led to a decrease in the content of tightly bound moisture in the samples, and to an increase in mass loss during the heat treatment of cutlets.

Given the changes in the physicochemical parameters of cutlets during storage, we studied the dynamics of their structural and mechanical characteristics during storage (Tables 3, 4, 5).

Table 3. Change in the depth of penetration of cutlets during storage.

\begin{tabular}{|c|c|c|c|c|c|c|c|c|}
\hline \multirow[b]{3}{*}{$\begin{array}{l}\text { Name of } \\
\text { indicator }\end{array}$} & \multicolumn{8}{|c|}{ Shelf life, day } \\
\hline & \multicolumn{2}{|c|}{0} & \multicolumn{2}{|c|}{36} & \multicolumn{2}{|c|}{72} & \multicolumn{2}{|c|}{108} \\
\hline & $\begin{array}{c}\text { Jerusale } \\
\text { m } \\
\text { artichoke } \\
\text { tubers } \\
\text { without } \\
\text { powder }\end{array}$ & $\begin{array}{c}\text { Cutlets } \\
\text { with } \\
\text { powder } \\
\text { from } \\
\text { Jerusale } \\
\text { m } \\
\text { artichoke } \\
\text { tubers }\end{array}$ & $\begin{array}{c}\text { Jerusale } \\
\mathrm{m} \\
\text { artichoke } \\
\text { tubers } \\
\text { without } \\
\text { powder }\end{array}$ & $\begin{array}{c}\text { Cutlets } \\
\text { with } \\
\text { powder } \\
\text { from } \\
\text { Jerusale } \\
\text { m } \\
\text { artichoke } \\
\text { tubers }\end{array}$ & 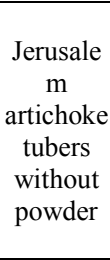 & $\begin{array}{c}\text { Cutlets } \\
\text { with } \\
\text { powder } \\
\text { from } \\
\text { Jerusale } \\
\text { m } \\
\text { artichoke } \\
\text { tubers }\end{array}$ & $\begin{array}{c}\text { Jerusale } \\
\text { m } \\
\text { artichoke } \\
\text { tubers } \\
\text { without } \\
\text { powder }\end{array}$ & $\begin{array}{l}\text { Cutlets } \\
\text { with } \\
\text { powder } \\
\text { from } \\
\text { Jerusale } \\
\text { m } \\
\text { artichoke } \\
\text { tubers }\end{array}$ \\
\hline $\begin{array}{l}\text { Penetrati } \\
\text { on depth, } \\
\text { M } \times 10^{-3}\end{array}$ & $\begin{array}{c}59.92 \pm 0 \\
11\end{array}$ & $\begin{array}{c}61.89 \pm 0 \\
17\end{array}$ & $\begin{array}{c}58.77 \pm 0 \\
22\end{array}$ & $\begin{array}{c}61.23 \pm 0 \\
15\end{array}$ & $\begin{array}{c}57.34 \pm 0 \\
15\end{array}$ & $\begin{array}{c}60.65 \pm 0 \\
25\end{array}$ & $\begin{array}{c}55.45 \pm 0 \\
19\end{array}$ & $\begin{array}{c}59.57 \pm 0 \\
21\end{array}$ \\
\hline
\end{tabular}

The data of table 3 indicate that within 108 days of storage in the studied samples of cutlets, a decrease in the depth of penetration was noted. So, on the 108th day of storage, the value of the depth of penetration in cutlets without powder from Jerusalem artichoke tubers and cutlets with powder from Jerusalem artichoke tubers decreased by $7.46 \%$ and $3.75 \%$, respectively. 
Table 4. Change in the cutoff voltage limit of cutlets during storage.

\begin{tabular}{|c|c|c|c|c|c|c|c|c|}
\hline \multirow[b]{3}{*}{$\begin{array}{l}\text { Name of } \\
\text { indicator }\end{array}$} & \multicolumn{8}{|c|}{ Shelf life, day } \\
\hline & \multicolumn{2}{|c|}{0} & \multicolumn{2}{|c|}{36} & \multicolumn{2}{|c|}{72} & \multicolumn{2}{|c|}{108} \\
\hline & $\begin{array}{c}\text { Jerusalem } \\
\text { artichoke } \\
\text { tubers } \\
\text { without } \\
\text { powder }\end{array}$ & $\begin{array}{l}\text { Cutlets } \\
\text { with } \\
\text { powder } \\
\text { from } \\
\text { Jerusalem } \\
\text { artichoke } \\
\text { tubers }\end{array}$ & $\begin{array}{c}\text { Jerusalem } \\
\text { artichoke } \\
\text { tubers } \\
\text { without } \\
\text { powder }\end{array}$ & $\begin{array}{l}\text { Cutlets } \\
\text { with } \\
\text { powder } \\
\text { from } \\
\text { Jerusalem } \\
\text { artichoke } \\
\text { tubers }\end{array}$ & $\begin{array}{c}\text { Jerusalem } \\
\text { artichoke } \\
\text { tubers } \\
\text { without } \\
\text { powder }\end{array}$ & $\begin{array}{l}\text { Cutlets } \\
\text { with } \\
\text { powder } \\
\text { from } \\
\text { Jerusalem } \\
\text { artichoke } \\
\text { tubers }\end{array}$ & $\begin{array}{c}\text { Jerusalem } \\
\text { artichoke } \\
\text { tubers } \\
\text { without } \\
\text { powder }\end{array}$ & $\begin{array}{l}\text { Cutlets } \\
\text { with } \\
\text { powder } \\
\text { from } \\
\text { Jerusalem } \\
\text { artichoke } \\
\text { tubers }\end{array}$ \\
\hline $\begin{array}{c}\text { Cutoff } \\
\text { stress, } \\
\mathrm{kPa}\end{array}$ & 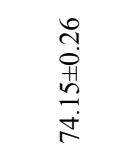 & 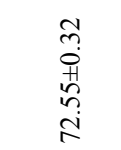 & 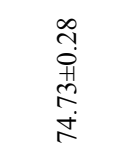 & $\begin{array}{l}n \\
m \\
0 \\
0 \\
0 \\
m \\
n\end{array}$ & 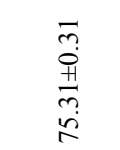 & 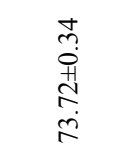 & $\begin{array}{l}\stackrel{+}{1} \\
0 \\
+1 \\
6 \\
0 \\
0\end{array}$ & 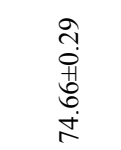 \\
\hline
\end{tabular}

The values of the ultimate shear stress (Table 4) for the entire storage period increased in cutlet samples without powder from Jerusalem artichoke tubers and with powder from Jerusalem artichoke tubers by $3,40 \%$ and $2,91 \%$, respectively.

The value of the cutting work (Table 5) during 108 days of storage increased in cutlets without powder from Jerusalem artichoke tubers by $3,75 \%$, in cutlets with powder from Jerusalem artichoke tubers - by $2,36 \%$.

It was found that during storage the consistency of cutlets gradually compacted, and rigidity increased. Changes in the structural and mechanical properties of cutlets can be explained by a decrease in the mass fraction of moisture during freezing and during storage of samples. It should be noted that during the entire storage period, cutlets with powder from Jerusalem artichoke tubers had a more delicate and soft consistency compared to cutlets without powder from Jerusalem artichoke tubers.

Table 5. The Change in the work of cutting cutlets during storage.

\begin{tabular}{|c|c|c|c|c|c|c|c|c|}
\hline \multirow[b]{3}{*}{$\begin{array}{l}\text { Name } \\
\text { of } \\
\text { indica } \\
\text { tor }\end{array}$} & \multicolumn{8}{|c|}{ Shelf life, day } \\
\hline & \multicolumn{2}{|c|}{0} & \multicolumn{2}{|c|}{36} & \multicolumn{2}{|c|}{72} & \multicolumn{2}{|c|}{108} \\
\hline & $\begin{array}{c}\text { Jerusalem } \\
\text { artichoke } \\
\text { tubers } \\
\text { without } \\
\text { powder }\end{array}$ & $\begin{array}{c}\text { Cutlets } \\
\text { with } \\
\text { powder } \\
\text { from } \\
\text { Jerusalem } \\
\text { artichoke } \\
\text { tubers }\end{array}$ & $\begin{array}{c}\text { Jerusalem } \\
\text { artichoke } \\
\text { tubers } \\
\text { without } \\
\text { powder }\end{array}$ & $\begin{array}{l}\text { Cutlets } \\
\text { with } \\
\text { powder } \\
\text { from } \\
\text { Jerusalem } \\
\text { artichoke } \\
\text { tubers } \\
\end{array}$ & $\begin{array}{c}\text { Jerusalem } \\
\text { artichoke } \\
\text { tubers } \\
\text { without } \\
\text { powder }\end{array}$ & $\begin{array}{l}\text { Cutlets } \\
\text { with } \\
\text { powder } \\
\text { from } \\
\text { Jerusalem } \\
\text { artichoke } \\
\text { tubers }\end{array}$ & $\begin{array}{c}\text { Jerusalem } \\
\text { artichoke } \\
\text { tubers } \\
\text { without } \\
\text { powder }\end{array}$ & $\begin{array}{l}\text { Cutlets } \\
\text { with } \\
\text { powder } \\
\text { from } \\
\text { Jerusalem } \\
\text { artichoke } \\
\text { tubers } \\
\end{array}$ \\
\hline $\begin{array}{c}\text { Work } \\
\text { of } \\
\text { cuttin } \\
\mathrm{g}, \mathrm{j} / \\
\mathrm{m} 2\end{array}$ & 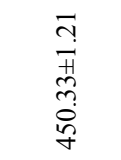 & 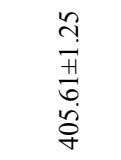 & 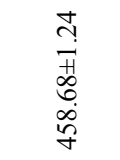 & 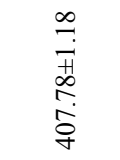 & 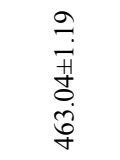 & 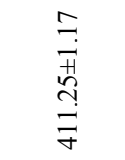 & 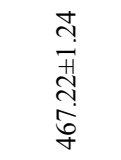 & $\begin{array}{l}\stackrel{2}{+} \\
\frac{H}{a} \\
\frac{n}{7}\end{array}$ \\
\hline
\end{tabular}

We have studied the hydrolytic and oxidative changes occurring in the lipids of cutlets during storage in a frozen state (Table 6).

It was found that the acid number of cutlets without powder from Jerusalem artichoke tubers and with powder from Jerusalem artichoke tubers increased over 108 days of storage in 4,19 and 3,85 times, respectively. The most intensive increase in acid numbers by 2,38 and 2,49 times, respectively, was observed in the first 36 days of storage.

As a result of the studies, it was found that the lipid peroxide numbers of cutlets without powder from Jerusalem artichoke tubers and with powder from Jerusalem artichoke tubers increased after 108 days by 3,31 and 2,57 times, respectively. From the data given in table 6 , it can be seen that in patties with Jerusalem artichoke tubers powder, the accumulation of 
peroxide compounds, characterized by a peroxide number, proceeds more slowly during storage compared to patties without Jerusalem artichoke tubers powder. This can be explained by the vitamin $\mathrm{C}$ content in patties with Jerusalem artichoke tubers powder 3,93 times higher than its content in the control sample. As you know, vitamin $\mathrm{C}$ is a natural antioxidant.

Table 6. Dynamics of acid, peroxide and thiobarbituric lipid numbers of frozen cutlets during storage.

\begin{tabular}{|l|c|c|c|c|}
\hline \multirow{2}{*}{$\begin{array}{l}\text { Name of } \\
\text { indicator }\end{array}$} & Shelf life, day & $\begin{array}{c}\text { Acid number, mg } \\
\mathrm{KOH}\end{array}$ & $\begin{array}{c}\text { Peroxide value, } \\
\text { mmol act O2 }\end{array}$ & $\begin{array}{c}\text { Thiobarbituric } \\
\text { number nmol MDA } \\
\text { per 1 g of product }\end{array}$ \\
\hline \multirow{2}{*}{$\begin{array}{l}\text { Jerusalem } \\
\text { artichoke } \\
\text { tubers without } \\
\text { powder }\end{array}$} & 0 & $1.36 \pm 0.09$ & $2.10 \pm 0.08$ & $377.25 \pm 4.33$ \\
\cline { 2 - 5 } & 36 & $3.25 \pm 0.12$ & $3.71 \pm 0.12$ & $429.18 \pm 5.10$ \\
\hline \cline { 2 - 5 } $\begin{array}{l}\text { Cutlets with } \\
\text { powder from }\end{array}$ & 12 & $4.82 \pm 0.11$ & $6.00 \pm 0.11$ & $581.23 \pm 6.32$ \\
\cline { 2 - 5 } $\begin{array}{l}\text { Jerusalem } \\
\text { artichoke } \\
\text { tubers }\end{array}$ & 0 & $5.71 \pm 0.12$ & $6.95 \pm 0.14$ & $679.00 \pm 4.38$ \\
\cline { 2 - 5 } & 76 & $2.16 \pm 0.09$ & $1.64 \pm 0.12$ & $339.11 \pm 3.49$ \\
\cline { 2 - 5 } & 108 & $4.19 \pm 0.13$ & $2.25 \pm 0.13$ & $428.02 \pm 6.54$ \\
\hline
\end{tabular}

We found that during 108 days of storage of cutlets, the thiobarbituric number increased on average by 1,8 times, compared with 0 days.

The results of studies of the total microbial contamination of cutlets during storage in the frozen state are presented in table 7.

Table 7. The Dynamics of microbiological quality indicators of cutlets during storage.

\begin{tabular}{|c|c|c|c|c|c|c|c|c|}
\hline \multirow[b]{3}{*}{$\begin{array}{l}\text { Name of } \\
\text { indicator }\end{array}$} & \multicolumn{8}{|c|}{ Shelf life, day } \\
\hline & \multicolumn{2}{|c|}{0} & \multicolumn{2}{|c|}{36} & \multicolumn{2}{|c|}{72} & \multicolumn{2}{|c|}{108} \\
\hline & $\begin{array}{l}\text { Jerusale } \\
\text { m } \\
\text { artichoke } \\
\text { tubers } \\
\text { without } \\
\text { powder }\end{array}$ & $\begin{array}{c}\text { Cutlets } \\
\text { with } \\
\text { powder } \\
\text { from } \\
\text { Jerusale } \\
\text { m } \\
\text { artichoke } \\
\text { tubers }\end{array}$ & $\begin{array}{l}\text { Jerusale } \\
\text { m } \\
\text { artichoke } \\
\text { tubers } \\
\text { without } \\
\text { powder }\end{array}$ & $\begin{array}{c}\text { Cutlets } \\
\text { with } \\
\text { powder } \\
\text { from } \\
\text { Jerusale } \\
\text { m } \\
\text { artichoke } \\
\text { tubers }\end{array}$ & $\begin{array}{l}\text { Jerusale } \\
\text { m } \\
\text { artichoke } \\
\text { tubers } \\
\text { without } \\
\text { powder }\end{array}$ & $\begin{array}{l}\text { Cutlets } \\
\text { with } \\
\text { powder } \\
\text { from } \\
\text { Jerusale } \\
\text { m } \\
\text { artichoke } \\
\text { tubers }\end{array}$ & $\begin{array}{l}\text { Jerusale } \\
\text { m } \\
\text { artichoke } \\
\text { tubers } \\
\text { without } \\
\text { powder }\end{array}$ & $\begin{array}{l}\text { Cutlets } \\
\text { with } \\
\text { powder } \\
\text { from } \\
\text { Jerusalem } \\
\text { artichoke } \\
\text { tubers }\end{array}$ \\
\hline $\begin{array}{c}\text { The } \\
\text { number } \\
\text { of } \\
\text { mesophili } \\
\text { c aerobic } \\
\text { and } \\
\text { facultativ } \\
\text { ely } \\
\text { anaerobic } \\
\text { microorg } \\
\text { anisms, } \\
\text { CFU / g }\end{array}$ & $2.5 \cdot 10^{6}$ & $2.1 \cdot 10^{6}$ & $2.3 \cdot 10^{6}$ & $1.8 \cdot 10^{6}$ & $3.2 \cdot 10^{6}$ & $3.0 \cdot 10^{6}$ & $4.5 \cdot 10^{6}$ & $3.5 \cdot 10^{6}$ \\
\hline $\begin{array}{c}\text { Group } \\
\text { bacteria } \\
\text { colibacill } \\
\mathrm{i}\end{array}$ & $\begin{array}{c}\text { are } \\
\text { absent }\end{array}$ & $\begin{array}{c}\text { are } \\
\text { absent }\end{array}$ & $\begin{array}{c}\text { are } \\
\text { absent }\end{array}$ & $\begin{array}{c}\text { are } \\
\text { absent }\end{array}$ & $\begin{array}{c}\text { are } \\
\text { absent }\end{array}$ & $\begin{array}{c}\text { are } \\
\text { absent }\end{array}$ & $\begin{array}{c}\text { are } \\
\text { absent }\end{array}$ & are absent \\
\hline $\begin{array}{l}\text { Mold } \\
\text { fungi }\end{array}$ & $\begin{array}{c}\text { are } \\
\text { absent }\end{array}$ & $\begin{array}{c}\text { are } \\
\text { absent }\end{array}$ & $\begin{array}{c}\text { are } \\
\text { absent }\end{array}$ & $\begin{array}{c}\text { are } \\
\text { absent }\end{array}$ & $\begin{array}{c}\text { are } \\
\text { absent }\end{array}$ & $\begin{array}{c}\text { are } \\
\text { absent }\end{array}$ & $\begin{array}{c}\text { are } \\
\text { absent }\end{array}$ & are absent \\
\hline
\end{tabular}

It was found that on the 36th day of storage, a decrease in the total number of microorganisms in the cutlet samples was observed, which is a consequence of the death of some microorganisms during freezing. With further storage, an increase in the amount of 
KMAFAnM was observed in cutlet samples without powder from Jerusalem artichoke tubers and with powder from Jerusalem artichoke tubers. Thus, the amount of KMAFAnM in cutlets without powder from Jerusalem artichoke tubers and cutlets with powder from Jerusalem artichoke tubers increased 1,8 and 1,7 times, respectively, during 108 days of storage.

Bacteria of the group of Escherichia coli and molds in the studied cutlets were not detected during the entire storage period.

\section{Discussion}

The study of changes in the consumer properties of meatballs with powder from Jerusalem artichoke tubers during storage showed that they are characterized by greater stability of consumer properties compared to meatballs without powder from Jerusalem artichoke tubers.

During freezing and subsequent storage of cutlets, a decrease in water binding capacity and an increase in losses during heat treatment were noted. It should be noted that these changes were less pronounced in cutlets with powder from Jerusalem artichoke tubers, compared with cutlets without powder from Jerusalem artichoke tubers.

It was found that cutlets with powder from Jerusalem artichoke tubers produced with powder from Jerusalem artichoke tubers showed a lower level of lipid oxidation compared to cutlets without powder from Jerusalem artichoke tubers.

The results of the tasting evaluation confirmed the high quality of venison cutlets with Jerusalem artichoke tubers powder.

\section{Conclusions}

The effect of Jerusalem artichoke tubers powder on the stability of consumer properties of venison cutlets during storage was studied. It was found that the powder from Jerusalem artichoke tubers positively affects the consumer properties of cutlets, since during storage the quality of cutlets from venison with powder from Jerusalem artichoke tubers changed to a lesser extent compared to the control sample of cutlets.

\section{References}

1. I.A. Zachesova, S.V. Kolobov, O.V. Orlova Reindeer meat as an alternative to solving the problem of import substitution of meat raw materials 1, 70-73 (2016)

2. I.A. Zachesova, S.V. Kolobov, A.I. Sapozhnikova Analysis of consumer preferences in the market of meat semi-finished products of the Moscow region Commodity expert of food products 5, 43- 51 (2017)

3. V.G Shelepov, V.A Uglov, E.V Boroday, Poznyakovsky V.M. Chemical composition of indigenous raw meats, Foods and Raw Materials 7(2), 412-418 (2019)

4. O.L. Ladnova and E.G. Merkulova Application of inulin and stevia for development of new generation products, Advances in Current Natural Sciences 2, 46-47 (2008)

5. Y. LinxiThe prospects of Jerusalem artichoke in functional food ingredients and bioenergy production Biotechnology Reports 5, 77-88 (2015)

6. B. Öztürk, M. Serdaroğlu, C. Tanışan, G. Çarkacı Quality characteristics of meatballs produced with jerusalem artichoke powder 61st International Congress of Meat Science and Technology. - Clermont-Ferrand, France (2015) 
7. Gribowski Effect of thermochemical treatment on the structure of inulin and its gelling properties. International, Journal of Food Science and Technology 43, 2075-2082 (2008)

8. S. J. Kays, S. F. Nottingham Biology and Chemistry of Jerusalem Artichoke Helianthus tuberosus L. Boca Raton, CRC Taylor \& Francis Group, 459 (2008)

9. T.V. Barkhatova, M.N. Nazarenko, M.A. Kozhukhova Obtaining and identification of inulin from Jerusalem artichoke (Helianthus tuberosus) tubers, Foods and Raw Materials 3, 2, 13-22 (2015)

10. M.B. Roberfroid Inulin - type fructans: functional food ingredients. $J$. Nutr., 137, 11, 2493-2502. (2000)

11. M.N. Nazarenko, T.V. Barkhatova, M.A. Kozhukhova Inulin changes in Jerusalem artichoke tubers during storage. Scientific, Journal of KubSAU, 10, no. 94. (2013)

12. L.B. Dzantieva Nutrients of Jerusalem artichoke tubers. Zemledeliye, 4, 33. (2006)

13. O.N. Savchenko The use of wild animal meat in the technology of meat products and modernity, 24, 220-224 (2013) 